The Canadian Mineralogist

Vol. 43, pp. 1291-1303 (2005)

\title{
IDENTIFICATION AND ALTERATION TRENDS OF GRANITIC-PEGMATITE-HOSTED (Y,REE,U,Th)-(Nb,Ta,Ti) OXIDE MINERALS: A STATISTICAL APPROACH
}

\author{
T. SCOTT ERCIT $\$$ \\ Canadian Museum of Nature, P.O. Box 3443, Station D, Ottawa, Ontario K1P 6P4, Canada
}

\begin{abstract}
The (Y,REE,U,Th)-(Nb,Ta,Ti) oxide minerals in REE-enriched granitic pegmatite and A- and I-type granites are primarily comprised of the fergusonite, samarskite, euxenite, aeschynite and pyrochlore groups. They are typically metamict and altered, and can be difficult to identify on a structural basis (XRD); consequently, examination of sample composition may be the most reliable approach to their identification. Canonical discriminant analysis can be used to discriminate among the various groups, and to assess the style and degree of alteration affecting samples. Identification of individual species should be made on the basis of previously published guidelines or, in their absence, on the basis of the "50\% rule" of the IMA. Vector analysis shows that alteration typically pushes the compositions of samarskite-, euxenite- and aeschynite-group minerals in a direction that causes them to resemble pyrochlore-group minerals. For this reason, it has been historically difficult to determine the exact nature of "viethofingite", "hjelmite" and "ampangabeite"; all are shown to be altered varieties of samarskite-group minerals. Yttrotantalite$(\mathrm{Y})$ is shown to be a member of the samarskite group, not the fergusonite group.
\end{abstract}

Keywords: statistical analysis, classification, pyrochlore, samarskite, fergusonite, euxenite, aeschynite, yttrotantalite-(Y), "viethofingite", "hjelmite", "ampangabeite", granitic pegmatite.

\section{SOMMAIRE}

Les oxydes à (Y,REE,U,Th)-(Nb,Ta,Ti) retrouvés dans les pegmatites granitiques enrichies en terres rares et dans les granites de types A et I font surtout partie des groupes fergusonite, samarskite, euxénite, aeschynite et pyrochlore. Ils sont typiquement métamictes et altérés, et peuvent donc alors être difficiles à identifier structuralement, par diffraction X; par conséquent, un examen de la composition d'un échantillon pourrait s'avérer la façon la plus fiable d'effectuer l'identification. Une analyse par discrimination canonique sert à distinguer les divers groupes, et à en évaluer le style et le degré d'altération. L'identification des espèces individuelles devrait être faite en fonction des conventions déjà dans la littérature ou de la règle dite des $50 \%$ de l'Association Internationale de Minéralogie. D'après une analyse vectorielle, l'altération déplace les compositions des minéraux des groupes samarskite, euxénite et aeschynite dans une direction qui les fait ressembler à des membres du groupe du pyrochlore. Pour cette raison, il a toujours été difficile de déterminer la nature exacte de la "viethofingite", la "hjelmite" et la "ampangabéite"; tous seraient des variétés altérées de minéraux du groupe de la samarskite. L'yttrotantalite-(Y) ferait partie du groupe de la samarskite, et non de la fergusonite.

(Traduit par la Rédaction)

Mots-clés: analyse statistique, classification, pyrochlore, samarskite, fergusonite, euxénite, aeschynite, yttrotantalite-(Y), "viethofingite", "hjelmite", "ampangabeite", pegmatite granitique.

\section{INTRODUCTION}

The (Y,REE,U,Th)-(Nb,Ta,Ti) oxide minerals are nearly ubiquitous constituents of REE-enriched granitic pegmatite, but much less so of A- and I-type granites (Ercit 2006). They consist of many mineral groups and individual species; the only prominent ones are minerals of the euxenite, aeschynite, pyrochlore, samarskite and fergusonite groups. An obstacle to their use in studies of the petrogenesis and evolution of granitic pegma- tite occurrences is the generally poor knowledge of their definition and crystal chemistry. The minerals are usually metamict, and heating experiments can fail to reconstitute the original structure (e.g., Ewing 1975). As such, phase identification commonly must be made without structural data, i.e., on the basis of compositional data alone. The principal objective of the current study is to use statistical methods to develop and evaluate identification techniques based solely on compositional data for these minerals. Secondary

§ E-mail address: sercit@mus-nature.ca 
objectives involve the application of such methods to evaluate alteration and resolve ambiguous identifications of samples in the literature and in the Canadian Museum of Nature Mineral Collection (CMNMC).

\section{BACKGROUND INFORMATION}

Minerals of the aeschynite and euxenite groups have the general formula $A B_{2} \mathrm{O}_{6}$, where $A$ stands for $\mathrm{Y}$, the rare-earth elements (REE), $\mathrm{Ca}$ and $\mathrm{U}$, and $B$, for $\mathrm{Ti}, \mathrm{Nb}$ and $\mathrm{Ta}$. The (Y,REE,U,Th)-(Nb,Ta,Ti) oxide members of the aeschynite group and their ideal compositions are aeschynite-(Y), $\mathrm{Y}(\mathrm{Ti}, \mathrm{Nb})_{2} \mathrm{O}_{6}$, aeschynite-(Ce), $\mathrm{Ce}(\mathrm{Ti}, \mathrm{Nb})_{2} \mathrm{O}_{6}$, aeschynite- $(\mathrm{Nd})$, $\mathrm{Nd}(\mathrm{Ti}, \mathrm{Nb})_{2} \mathrm{O}_{6}$, nioboaeschynite-(Ce), $\mathrm{Ce}(\mathrm{Nb}, \mathrm{Ti})_{2} \mathrm{O}_{6}$, nioboaeschynite-( $\mathrm{Nd}), \mathrm{Nd}(\mathrm{Nb}, \mathrm{Ti}){ }_{2} \mathrm{O}_{6}$ and tantalaeschynite-(Y), $\mathrm{Y}(\mathrm{Ta}, \mathrm{Ti}, \mathrm{Nb})_{2} \mathrm{O}_{6}$. Members of the euxenite group include euxenite- $(\mathrm{Y}), \mathrm{Y}(\mathrm{Nb}, \mathrm{Ti})_{2} \mathrm{O}_{6}$, tanteuxenite-(Y), $\mathrm{Y}(\mathrm{Ta}, \mathrm{Ti}, \mathrm{Nb})_{2} \mathrm{O}_{6}$, polycrase-(Y), $\mathrm{Y}(\mathrm{Ti}, \mathrm{Nb})_{2} \mathrm{O}_{6}$, and uranopolycrase, $\mathrm{UTi}_{2} \mathrm{O}_{6}$. The aeschynite structure shows a preference for larger $A$ cations than the euxenite structure; hence aeschynitegroup minerals have a higher LREE : (Y + HREE) ratio than euxenite-group minerals (Ewing 1976). Given the general preference of REE-enriched granitic pegmatite toward relatively high Y + HREE contents and low LREE contents, LREE-dominant members of the aeschynite group are rare to absent. Aeschynite-group minerals ideally have Pbnm symmetry, with $a 10.9, b$ 7.5, c $5.2 \AA$, whereas euxenite-group minerals ideally have Pbcn symmetry, with $a 14.6, b 5.6, c 5.2 \AA$. For both groups, the dominant end-members with Y and REE as the $A$ cation require a $B$ cation with a net charge of $4.5+$; hence the $B$ position of the formula is occupied by approximately equal amounts of pentavalent and tetravalent ions. Compositions with Ti dominant at $B$ require an $A$ cation with a net charge higher than $3+$; some degree of substitution of $(\mathrm{Y}, \mathrm{REE})^{3+}$ by $(\mathrm{U}, \mathrm{Th})^{4+}$ and $\mathrm{U}^{6+}$ fulfills this requirement. Compositions with $\mathrm{Nb}$ or Ta dominant at $B$ require an $A$ cation with a net charge lower than $3+; \mathrm{Ca}^{2+}$ fulfills this requirement.

Members of the pyrochlore group are cubic, $F d 3 m, a \approx 10.4 \AA$, with the general formula $A_{2-x}$ $B_{2}(\mathrm{O}, \mathrm{OH})_{6}\left(\mathrm{OH}, \mathrm{F}, \mathrm{H}_{2} \mathrm{O}\right)_{1-y}$. The group is divided into three subgroups: the betafite subgroup with $2 \mathrm{Ti} \geq(\mathrm{Ta}+$ $\mathrm{Nb}$ ) at the $B$ position of the formula, and the pyrochlore and microlite subgroups, in which $(\mathrm{Nb}+\mathrm{Ta})>2 \mathrm{Ti}$ and $\mathrm{Nb}>\mathrm{Ta}$ (pyrochlore) or $\mathrm{Ta} \geq \mathrm{Nb}$ (microlite). A wide variety of large, mostly mono- to trivalent cations are possible at the $A$ position, resulting in a high number of end members. The most important members of the pyrochlore group to occur in REE-enriched granitic pegmatite are pyrochlore, $(\mathrm{Ca}, \mathrm{Na})_{2-x} \mathrm{Nb}_{2} \mathrm{O}_{6}\left(\mathrm{OH}, \mathrm{F}, \mathrm{H}_{2} \mathrm{O}\right)_{1-y}$, betafite, $(\mathrm{Ca}, \mathrm{Na})_{2-x} \mathrm{Ti}_{2} \mathrm{O}_{6}\left(\mathrm{OH}, \mathrm{F}, \mathrm{H}_{2} \mathrm{O}\right)_{1-y}$, uranpyrochlore, $\mathrm{U}_{2-x} \mathrm{Nb}_{2} \mathrm{O}_{6}\left(\mathrm{OH}, \mathrm{F}, \mathrm{H}_{2} \mathrm{O}\right)_{1-y}$, yttropyrochlore$(\mathrm{Y}), \mathrm{Y}_{2-x} \mathrm{Nb}_{2} \mathrm{O}_{6}\left(\mathrm{OH}, \mathrm{F}, \mathrm{H}_{2} \mathrm{O}\right)_{1-y}$, yttrobetafite-(Y), $\mathrm{Y}_{2-x} \mathrm{Ti}_{2} \mathrm{O}_{6}\left(\mathrm{OH}, \mathrm{F}, \mathrm{H}_{2} \mathrm{O}\right)_{1-y}$, and the much rarer microlite,
$(\mathrm{Ca}, \mathrm{Na})_{2-x} \mathrm{Ta}_{2} \mathrm{O}_{6}\left(\mathrm{OH}, \mathrm{F}, \mathrm{H}_{2} \mathrm{O}\right)_{1-y}$, and uranmicrolite, $\mathrm{U}_{2-x} \mathrm{Ta}_{2} \mathrm{O}_{6}\left(\mathrm{OH}, \mathrm{F}, \mathrm{H}_{2} \mathrm{O}\right)_{1-y}$.

Members of the samarskite group have the general formula $\mathrm{ABO}_{4}$, where $A$ stands for Y, REE, Ca, $\mathrm{U}, \mathrm{Fe}^{2+}$ and $\mathrm{Fe}^{3+}$, and $B$, for $\mathrm{Ta}, \mathrm{Nb}$ and $\mathrm{Ti}$. A small but relatively common group, it is in some cases overlooked in general compendia (e.g., Burt 1989). Members of the group are samarskite-(Y), (Y,Ca, Fe) $\mathrm{NbO}_{4}$, calciosamarskite, $(\mathrm{Ca}, \mathrm{Y}, \mathrm{U}) \mathrm{NbO}_{4}$, and ishikawaite, (U,Fe,Y,Ca) $\mathrm{NbO}_{4}$ (Hanson et al. 1999, Warner \& Ewing 1993). Iron is a persistent, but subordinate $A$ cation. All members are ideally monoclinic $P 2 / c$, with $a 5.7, b 9.9$, c $5.2 \AA, \beta 94^{\circ}$.

Members of the fergusonite group also have the general formula $A B \mathrm{O}_{4}$, where $A$ stands for $\mathrm{Y}$ and REE, and $B$, for $\mathrm{Nb}$ and $\mathrm{Ta}$. The IMA-approved members of the group include fergusonite-(Y) [tetragonal $\left.\mathrm{YNbO}_{4}\right]$, beta-fergusonite-( $\left.\mathrm{Y}\right)$ [monoclinic $\left.\mathrm{YNbO}_{4}\right]$ and formanite-(Y) [monoclinic $\left.\mathrm{YTaO}_{4}\right]$. Other names in use refer to the carbonatite-hosted $\mathrm{Ce}$ and $\mathrm{Nd}$ analogues of fergusonite-(Y) and beta-fergusonite-(Y); however, their descriptions have been published without IMA approval. Fergusonite-(Y) ideally has $a$ 5.3, $c 10.9$ $\AA$, space group $I 4_{1} / a$. The monoclinic members $(I 2 / c)$ ideally have $a 5.3 b 11 c 5.1, \beta 95^{\circ}$. In general, the fergusonite structures would seem to be stable for higher values of the $\mathrm{A}: \mathrm{B}$ radius ratio than the samarskite structure.

\section{Statement of the Problem}

Despite the apparently straightforward definitions given above, it is difficult to differentiate amongst (Y,REE,U,Th)-(Nb,Ta,Ti) oxide minerals: (1) Actinideelement-bearing species and varieties are commonly completely metamict and variably altered. Heating commonly gives variable results as a function of temperature, and commonly produces composite powder-diffraction patterns (e.g., Ewing 1974). (2) The ubiquitous but variable degrees of alteration render older, bulk-chemical analyses of limited practical use. (3) Synthesis and annealing studies have not particularly been well matched to natural conditions of formation, leading to ambiguous [the results of Tsunekawa et al. (1995) do not match observations on natural fergusonite], contradictory [Mitchell (1967) versus Gong (1990)], or erroneous conclusions [see critiques of the "samarskite" study of Sugitani et al. (1985) in Hanson et al. (1999) and Warner \& Ewing (1993)]. (4) The gross similarities of many mineral formulae between groups, i.a., fergusonite versus samarskite and euxenite versus aeschynite, potentially lend a degree of confusion to sorting out identity on the basis of composition. Furthermore, variable numbers of vacancies in the cation and anion sites of pyrochlore-group minerals can make some compositions of betafite-subgroup minerals resemble euxenite- or aeschynite-group minerals. (5) 
Historically, varietal names abound in these groups, although many efforts have been made to reduce their number (e.g., Ewing 1976).

Ewing (1976) approached the classification of $A B_{2} \mathrm{O}_{6}$ (euxenite- and aeschynite-group) minerals by means of statistical analysis of compositional data. The approach was both novel and superbly suited to metamict oxide minerals; however, the study and its conclusions are rarely cited in the many studies that have followed. The probable reasons are manifold: (1) Ewing made use of statistical methods with which most mineralogists have no familiarity. (2) The coefficients of the discriminant analyses were published (Ewing 1974), but not the constants, thus others could not use the classification plots of Ewing $(1974,1976)$. (3) Statistical methods were used to classify the oxides, not crystal-chemical methods based on limits to solid solution, an approach that would win few supporters trained to think exclusively of the latter. (4) Rather than atoms per formula unit $(a p f u)$, oxide weight percentages were used in the classification. Although there is nothing mathematically untoward about this approach, the choice was not explained, and may have cost the study some of the consideration it warranted.

In my estimation, the approach of Ewing (1976) is currently the best one to adopt in classifying metamict (Y,REE,U,Th)-(Nb,Ta,Ti) oxide minerals, not just the $A B_{2} \mathrm{O}_{6}$ oxides. Modifications and clarifications to the approach of Ewing $(1974,1976)$ to be taken here are: (1) Use of statistical methods to determine group affiliations, but not to identify individual species. Once group affiliations are determined, formulae should be calculated and published definitions should be used in naming a species; failing such publications, the " $50 \%$ rule" of Nickel (1992) should be used. For example, polycrase-(Y) and euxenite-(Y) are most properly differentiated: if $\mathrm{Ti}$ exceeds $(\mathrm{Ta}+\mathrm{Nb})$, then the mineral is polycrase-(Y), and the reverse for euxenite-(Y). (3) Oxide wt. \% is to be used in the statistical analysis, not apfu for the following reasons: $i$ ) The purpose of statistical analysis is to determine group affiliation; without such knowledge, the bases for formula calculation are not known; ii) it makes no difference whether one uses oxide wt.\% or apfu in the statistical analysis. Without prior knowledge of group affiliation, unconstrained numbers of cations (no oxygen basis) or the same basis for formula calculation must be used for all species (i.e., a completely arbitrary number of oxygen $a p f u$ ). If $\boldsymbol{O}$ is a matrix consisting of the constituent oxide weight percentages of an analysis, $\boldsymbol{T}$ is a matrix consisting of the molecular weights of the constituent oxides, and $\boldsymbol{C}$ is a matrix consisting of an unconstrained number of cations, then $\boldsymbol{O T}=\boldsymbol{C}$. As $\boldsymbol{T}$ is a scalar, either $\boldsymbol{O}$ or $\boldsymbol{C}$ may be used in the statistical analysis.

\section{Data Collection and Analytical Methods}

Most data for this study of classification were selected from published studies of (Y,REE,U,Th)(Nb,Ta,Ti) oxide minerals from REE-enriched granitic pegmatite and, to a much lesser degree, from A- and I-type granites and their extrusive equivalents. Preference was given to microchemical analyses in which sample alteration was assessed, so that data representing heavily altered regions of samples could be avoided. For bulk analyses and microchemical analyses in which sample alteration was not assessed, only those representing relatively unaltered to mildly altered samples were used. The following criteria for inclusion were used: anhydrous (less essential hydroxyl) oxide sums in excess of $90 \mathrm{wt} . \%$, and low concentrations of "contaminant" elements such as Si and Al. Efforts were made to select compositions within each group that represent broad ranges of crystal-chemical substitution, so that the dataset as a whole encompassed as much of the full range of compositions found in REE-enriched pegmatite and A- and I-type granites.

Detailed studies of the alteration of euxenite-, aeschynite- and pyrochlore-group minerals exist (Ewing 1974, 1975, Lumpkin \& Ewing 1992, 1995, 1996); however, very little has been published in terms of sample alteration for members of the samarskite group. Consequently, new analytical data were obtained for these minerals, and some of these data were used to supplement the classification study. Samples of these samarskite-group minerals were selected from the CMNMC, and were chemically analyzed with a JEOL 733 electron microprobe with Tracor-Northern 5500 and 5600 automation. The operating voltage was $15 \mathrm{kV}$, the beam current, $20 \mathrm{nA}$, and the beam diameter, $20 \mu \mathrm{m}$. Samples were assessed for the degree and type of alteration by back-scattered electron (BSE) imaging. Data for standards were collected for $50 \mathrm{~s}$ or to $0.25 \%$ precision $(1 \sigma$ level $)$, whichever was attained first. Similarly, data for samples were collected for $25 \mathrm{~s}$ or to $0.5 \%$ precision, except for $\mathrm{Pb}$ and $\mathrm{F}$, which were counted for $100 \mathrm{~s}$ to improve detectability. An element was considered to be detected if it attained a significance level of $4 \sigma$ or better, as judged on the basis of count statistics. Data reduction was done with the ZAF routine in the Tracor-Northern TASK computer program. A wide variety of natural and synthetic standards was used for the 29 elements measured, a list too large to report here. The analytical results are available from the Depository of Unpublished Data, CISTI, National Research Council, Ottawa, Ontario K1A 0S2, Canada.

All statistical calculations were done with SYSTAT for Windows, version 10.2 (SYSTAT Software Inc. 2002), and principally involved the routines for canonical discriminant analysis. 


\section{StATISTICAL ANALYSIS}

\section{Characteristics of the dataset}

For the purposes of statistical analysis, all samples were assigned to one of four groupings, i.e., samarskite, fergusonite, pyrochlore, and euxenite-aeschynite. For the samarskite group, approximately equal numbers of samarskite-(Y) and calciosamarskite-(Y) samples were selected; because of their scarcity, fewer samples of ishikawaite were used. For the fergusonite group, because of the general scarcity of formanite-(Y), all samples but one are of fergusonite-(Y) or beta-fergusonite-(Y). For the pyrochlore group, approximately equal numbers of samples from the pyrochlore and betafite subgroups were used; for reasons of scarcity in REE-enriched pegmatite, fewer numbers of samples from the microlite subgroup were used. For the euxenite-aeschynite grouping, approximately equal numbers of euxenite, polycrase and aeschynite samples were used. In all, the sampling represented 20 different mineral species. Attempts also were made to normalize the sizes of the different groups, an important prerequisite to discriminant analysis. The exception was the fergusonite group (14 samples as compared to 19 samples of samarskite, 18 of pyrochlore and 22 of euxenite-aeschynite). This disparity is not a significant concern, as the fergusonite group shows much less compositional variability than the other groups, and as sample classification eventually migrated away from the use of the fergusonite group in statistical models (see below).

\section{Selection of variables}

Samples of (Y,REE,U,Th)-(Nb,Ta,Ti) oxide minerals from granitic pegmatite and granite show broad compositional variability. Results of electron-microprobe analyses commonly contain information for upward of twenty-five constituent oxides; consequently, efforts were made to reduce the number of variables. Because of their crystal-chemical and geochemical similarity, all oxides of the light rare-earth-elements (LREE: La to Eu) were combined to form one variable, as were oxides of the heavy rare-earth-elements (HREE: Gd to Lu). Yttrium behaves crystal-chemically and geochemically like the HREE, and might be included in the HREE tally; however, because of severe differences in weight between oxides of Y versus the HREE, the two were retained as separate entities. For similar reasons, oxides of $\mathrm{Nb}$, Ta and $\mathrm{W}$ were not summed to form one variable; $\mathrm{Nb}$ oxide was retained as one variable, and oxides of $\mathrm{Ta}$ plus $\mathrm{W}$ were summed to form another (Ta*). Because of the similar crystal-chemical behavior of $\mathrm{Fe}$ and $\mathrm{Mn}$, and weights of their oxides, all were summed to a single quantity, $\mathbf{F e}^{*}$. For analogous reasons, all oxides of Th and $\mathbf{U}$ were summed to form $\mathbf{U}^{*}$. One of the advantages of these combinations is that they prevent variations owing to geochemical systematics from playing a role in sample classification. Although much $\mathrm{Pb}$ in (Y,REE,U,Th)-(Nb,Ta,Ti) oxide minerals is radiogenic in origin, and as such might be incorporated into $\mathbf{U}^{*}$, for some of the oxide minerals, e.g., members of the pyrochlore group, major quantities of nonradiogenic $\mathrm{Pb}$ can be present; consequently, $\mathrm{Pb}$ oxide was retained as a separate variable. Many oxides were ignored in modeling because they play relatively insignificant roles in the crystal chemistry of (Y,REE,U,Th)-(Nb,Ta,Ti) oxide minerals hosted by REE-enriched pegmatite, e.g., $\mathrm{K}_{2} \mathrm{O}, \mathrm{MgO}, \mathrm{Sc}_{2} \mathrm{O}_{3}, \mathrm{ZrO}_{2}, \mathrm{HfO}_{2}$. Others were ignored because of their general introduction (adsorption) into structural voids in (Y,REE,U,Th)-(Nb,Ta,Ti) oxide minerals following metamictization, e.g., $\mathrm{SiO}_{2}$, $\mathrm{Al}_{2} \mathrm{O}_{3}$. Still others were ignored because they are not measured with any degree of historical consistency; for example, F concentration was commonly not measured with an electron microprobe prior to the late 1980s, and although typically reported in results of (older) wetchemical analyses, the amount of $\mathrm{H}_{2} \mathrm{O}$ is now rarely measured today owing to an exclusive reliance on electron-microprobe data. The final list of oxide variables selected for statistical modeling numbered 11: Na, Ca, Pb, Fe*, Y, LREE, HREE, U*, Ti, Nb, and Ta*. The list is similar to that used in Ewing (1974, 1976), but necessarily broader owing to the inclusion of additional mineral groups in the current study.

\section{Modeling}

Four-group model. The initial model involved discrimination of all four groups using the 11 compositional variables. Inspection of this model showed significant separation of the group means at the $99 \%$ confidence level on the basis of all conventional measures (Wilks's lambda, Pillai's trace, Lawley-Hotelling trace; SYSTAT Software Inc. 2002). Because of heavy "pruning" of the initial list of variables, uncertain dimensionality of potential submodels, the high degree of correlation of some of the variables (e.g., $\mathbf{P b}$ and $\left.\mathbf{U}^{*}\right)$, and because of a desire to compare different varieties of this model, complete estimation of the model, not stepwise regression, was used; i.e., the number of variables was fixed at the initial list of 11. Because of variable degrees of hydration and the omission of a number of oxides from the list, closure was not a problem for computations. The unjackknifed and jackknifed classification matrices (Tukey 1958, SYSTAT Software Inc. 2002) showed perfect classification of all cases (samples).

Because four groups were used in the analysis, $n-1$ $=3$ discriminant functions necessarily result. All three showed significant discriminating power: $55 \%$ of the total dispersion is accounted for by canonical variable $1,34 \%$ by variable 2 , and $11 \%$ by variable 3 . The three functions are: 
$\mathbf{C V 1}=0.172 \mathbf{~ N a}-0.027 \mathbf{C a}+0.058 \mathbf{F e}^{*}$

$+0.069 \mathbf{P b}-0.306 \mathbf{Y}-0.167$ LREE

-0.237 HREE $-0.093 \mathbf{U}^{*}+0.108 \mathrm{Ti}$

$-0.016 \mathbf{~ N b}-0.013 \mathbf{T a}^{*}+5.60$ (oxide wt. $\%$ )

$\mathbf{C V} 2=0.275 \mathbf{~ N a}+0.089 \mathbf{C a}-0.152 \mathbf{F e} *$

$+0.414 \mathbf{P b}+0.148 \mathbf{Y}+0.249$ LREE

+0.118 HREE + $0.067 \mathbf{U}^{*}+0.305 \mathbf{T i}+0.066 \mathbf{~ N b}$

+0.083 Ta* $^{*} 10.01$ (oxide wt. $\%$ )

$\mathbf{C V 3}=0.117 \mathbf{N a}+0.138 \mathbf{C a}+0.698 \mathbf{F e} *$

$+0.302 \mathbf{P b}+0.227 \mathbf{Y}+0.264$ LREE

+0.105 HREE + $0.136 \mathbf{U}^{*}+0.281 \mathbf{T i}+0.184 \mathbf{~ N b}$

+0.181 Ta* $^{*} 19.50$ (oxide wt. $\%$ )

where CV1, CV2 and CV3 are canonical variables 1, 2 and 3. Because of the significance of CV3, a single two-dimensional plot of CV2 versus CV1 potentially does not represent enough of the total dispersion to allow one to correctly classify all samples. Inspection of two-dimensional plots of the canonical scores for the various samples in the calibration dataset shows that CV3 primarily adds extra power to the discrimination between the samarskite and pyrochlore groups. Thus, except for samples that fall between samarskite and pyrochlore, a single plot of CV1 versus CV2 should suffice in differentiating amongst the various groups (Fig. 1).
Inspection of Figure 1 shows that samples of the fergusonite group are well separated from other (Y,REE,U,Th)-(Nb,Ta,Ti) oxide minerals. The samples of fergusonite thus may be so easily differentiated from the other groupings that they do not require inclusion in statistical models.

Three-group model. Statistical modeling followed the procedure described for the four-group model, with the exception that samples of the fergusonite group were removed from the dataset. The results were superficially similar to the four-group model, including the similar separations of group means, and the perfect classification of all cases in both the unjackknifed and jackknifed classification matrices. The three-group model necessarily resulted in two discriminant functions, thus all of the dispersion is contained within the two canonical variables (CV1: 61\%, CV2: 39\%). The functions are:

$\mathbf{C V 1}=0.245 \mathrm{Na}+0.106 \mathbf{C a}-0.077 \mathbf{F e}^{*}$

$+0.425 \mathbf{P b}+0.220 \mathbf{Y}+0.280$ LREE

+0.137 HREE + $0.100 \mathbf{U}^{*}+0.304 \mathbf{T i}+0.097 \mathbf{~ N b}$

+0.109 Ta* -12.81 (oxide wt. $\%$ )

$\mathbf{C V 2}=0.102 \mathbf{N a}-0.113 \mathbf{C a}-0.371 \mathbf{F e} *$

$-0.167 \mathbf{P b}-0.395 \mathbf{Y}-0.280$ LREE

-0.265 HREE $-0.182 \mathbf{U}^{*}-0.085 \mathrm{Ti}-0.166 \mathbf{~ N b}$

-0.146 Ta* $^{*} 17.29$ (oxide wt. $\%$ )

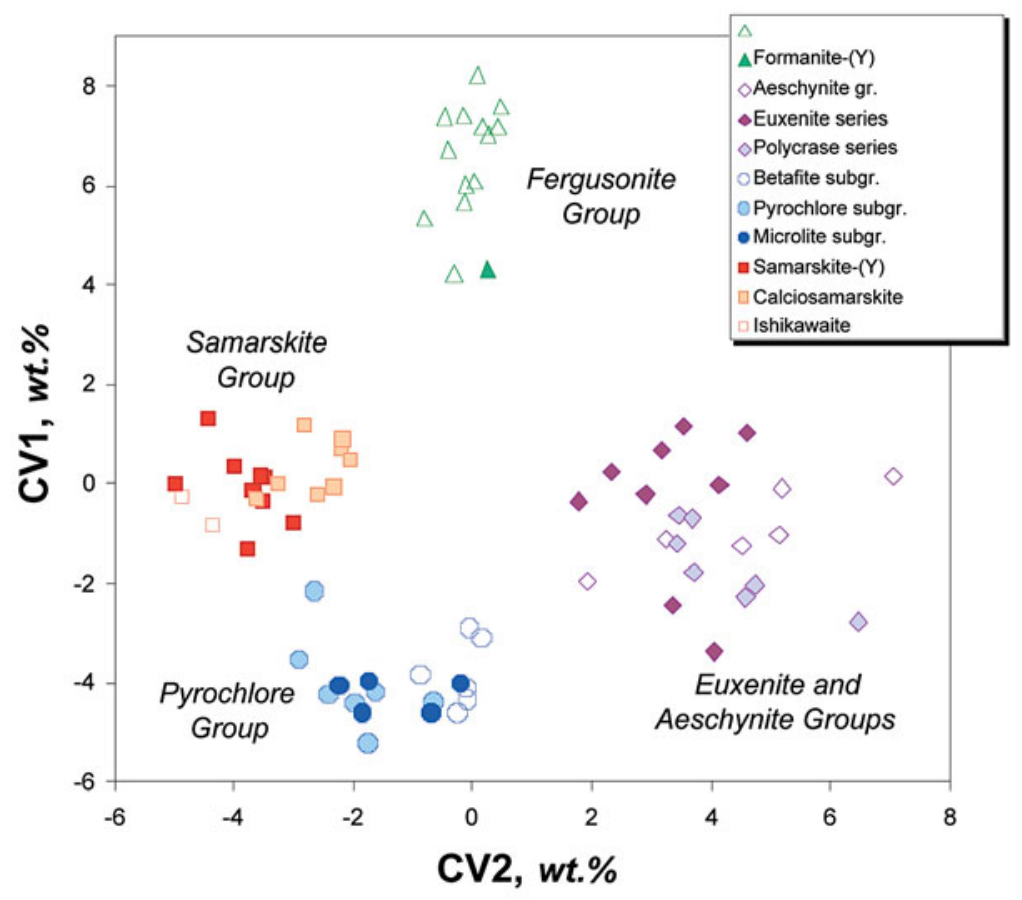

FIG. 1. Plot of the scores for canonical variables 1 and 2 of the four-group model. 
CV1 of this three-group model is very similar to CV2 of the four-group model; by deduction, much of the discriminating power of $\mathbf{C V 3}$ of the four-group model would seem to have been incorporated into $\mathbf{C V} 2$ of the three-group model. This fact is shown in Figure 2, a plot of CV2 versus CV1 for the three-group model, which cursorily looks much like Figure 1, except for inversion of the ordinate, and shows $\mathbf{C V 2}$ as an excellent discriminant of the samarskite versus pyrochlore groups. The boundaries of Figure 2 were derived from overlapping contour plots based on squared Mahalanobis distances from the three-group means (crosses in Fig. 2), from which the posterior probabilities for sample classification are derived.

Figure 2 also shows where members of the fergusonite group plot, on the basis of discriminant functions for the three-group model (i.e., below the dashed line). Given the similarities of some of the discriminant functions of the four-group model versus the three-group model, this location should be of little surprise. One could argue that Figure 2 approximates a different projection of the three-dimensional system represented in part by Figure 1, one in which separation of the pyrochlore, euxenite-aeschynite and samarskite group- ings is maximized at the expense of the fergusonite group. Because of the high degree of separation of the fergusonite group from the other groups in the threedimensional system, most of its members remain well separated within the approximate plane of projection represented by Figure 2. I conclude that Figure 2 should suffice for the classification of all groups.

It should be noted that neither Figures 1 nor 2 discriminate between the aeschynite and euxenite groups; however, this can be done using the results of Ewing (1974). From the published plots, group means and canonical coefficients of Ewing (1974), constants can be estimated for the discriminant function used in differentiating aeschynite- from euxenite-group minerals, corresponding to canonical variable 1 of Figure 5 in Ewing (1976). The result, albeit a working definition, is: if LREE > $0.326 \mathbf{T i}-0.060 \mathbf{~ N b}+3.1$ (oxide wt.\%), then the sample is a member of the aeschynite group; if the reverse, then it is a member of the euxenite group. What this relationship corresponds to crystal-chemically does not matter at present; for a proper distinction between the aeschynite and euxenite groups, synthesis studies are needed (i.e., to determine the compositional ranges for each structure type).

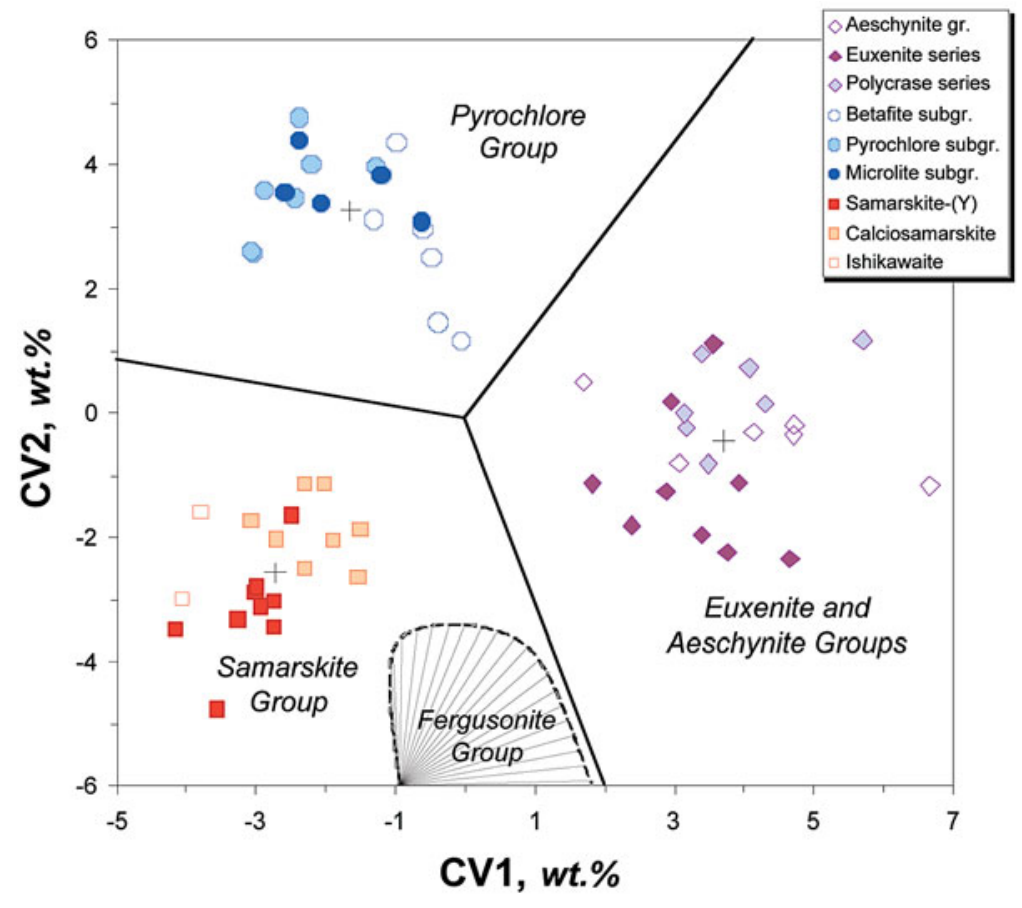

FIG. 2. Plot of the scores for canonical variables 1 and 2 of the three-group model. Crosses are group means. The region outlined in dashed rule shows where fergusonite-group minerals would plot. 


\section{APPLICATIONS}

\section{Degree of sample alteration}

The results of published studies (Ewing 1976, Lumpkin et al. 1986, Lumpkin \& Ewing 1992, 1995, 1996) show that six major effects dictate the behavior of (Y,REE,U,Th)-(Nb,Ta,Ti) oxide minerals during primary (magmatic to hydrothermal) and secondary (post-metamictization) alteration (terminology of Lumpkin \& Ewing 1992). These are: hydration, highfield-strength-element (HFSE) gain (particularly Si and Al), large-ion-lithophile-element (LILE) gain (particularly $\mathrm{K}, \mathrm{Ba}$ and $\mathrm{Sr}$, although of little importance in REE-enriched pegmatite), calcium addition, exchange of HREE and Y for LREE, and A-cation loss (particularly for pyrochlore-group minerals). These effects are illustrated in Figure 3. Hydration and the addition of $\mathrm{Si}, \mathrm{Al}, \mathrm{Ba}, \mathrm{K}$ and $\mathrm{Sr}$ are easiest to model, as all result in a lowering of the analytical total represented by the compositional variables used in the discriminant analysis. These effects result in an approximately uniform lowering of the concentrations of all of the elements used in modeling, thus they will push the canonical scores toward the intercepts of the discriminant functions at $(-12.81,17.29)$. This bulk effect is considered to be the most significant gain or loss in mass during the various forms of alteration (particularly secondary), thus the vector representing this effect is drawn as the longest of Figure 3 . The remaining exchange-vectors of Figure 3 were derived by adding fictive amounts of the various other components involved in alteration to typical compositions of (Y,REE,U,Th) -(Nb,Ta,Ti) oxide minerals. Addition of Ca produces a nearly vertical shift in canonical scores plotted in Figure 3, whereas A-cation loss and (Y + REE) exchange-vectors plot diagonally in Figure 3, approximately opposite each other. From Figure 3, one would predict that alteration of most (Y,REE,U,Th)-(Nb,Ta,Ti) oxide minerals will push the canonical scores toward smaller values of CV1 and, by the same token, larger values of CV2. Minor deviations from this trend are to be expected.

In order to test the predictions of Figure 3, studies were sought in which microchemical methods of analysis were used in characterizing fresh and altered regions of (Y,REE,U,Th)-(Nb,Ta,Ti) oxide minerals. For members of the euxenite and aeschynite groups, Ewing's (1974) is the best study to date; for members of the pyrochlore group, Lumpkin \& Ewing (1992, $1995,1996)$ offered the best analysis; however, to date, no comprehensive studies of the alteration of samarskite-group and fergusonite-group minerals have been done. As the present study focuses predominantly on the three-group model, namely in differentiating among minerals of the samarskite, pyrochlore, and euxenite-aeschynite groupings, new microchemical compositional data were obtained for variably altered members of the samarskite group.
Figure 4 illustrates the results for compositions from REE-enriched pegmatite in Ewing (1974). One immediate consequence of the calculation is to show that sample R11 of Ewing (1974) is actually a member of the samarskite group. Points for which both relatively fresh and altered regions were analyzed are connected by arrows, the tail of each denoting the fresh region, and the tip, the altered region. Most of the arrows are subparallel to the longest vector of Figure 3, indicating that hydration and addition of $\mathrm{Si}$ and $\mathrm{Al}$ are the predominant effects in the alteration of euxenite- and aeschynite-group minerals. By analogy with Figure 3, the one vector of Figure 4 that proceeds in a SW to NE direction is most likely attributable to ( $\mathrm{Y}+\mathrm{REE})$ exchange, and indeed, inspection of Ewing (1974: sample R16) shows that this is so.

Figure 5 illustrates the results for compositions from REE-enriched pegmatite in Lumpkin \& Ewing (1992, 1995, 1996). The two main vectors in Figure 5 are shallower in slope than the longest vector of Figure 3, indicating that alteration of pyrochlore-group minerals involves more than just hydration and addition of $\mathrm{Si}, \mathrm{Al}$ and LILE. The only vector component that can achieve this effect is $A$-cation loss, and for the samples shown in Figure 5, this is what has occurred (Lumpkin \& Ewing 1995, 1996: samples 130, 214). One sample of betafite (176) shows divergent compositions (Fig. 5), both of which represent significant amounts of secondary alteration. One composition plots well within the field of the pyrochlore group. The other plots within the field for the aeschynite-euxenite grouping; however, its composition indicates that it does not belong to the grouping (nearly devoid of Y + REE and calcium). Lumpkin \& Ewing (1992) indicated that the sample has undergone major amounts of element redistribution, and is in the

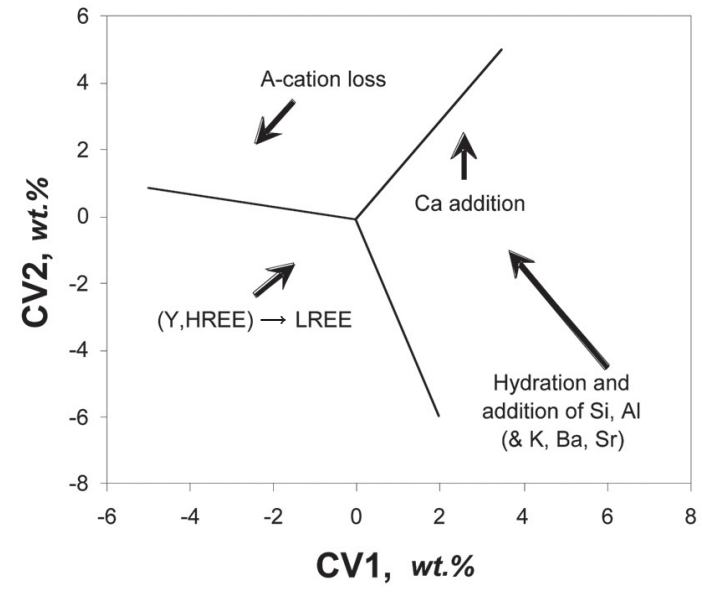

FIG. 3. Mass addition and loss vectors for the three-group model. 


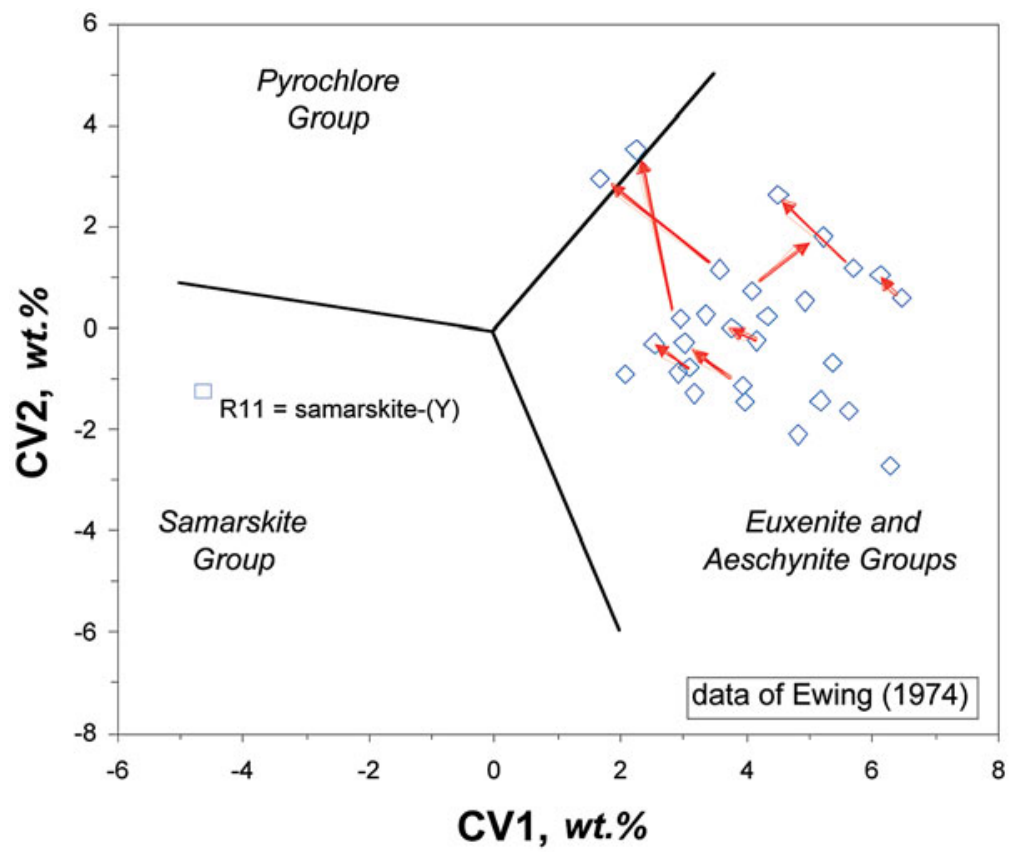

FIG. 4. Plot of the scores for samples of euxenite- and aeschynite-group minerals from REE-enriched granitic pegmatite, after Ewing (1974). Arrows denote alteration paths.

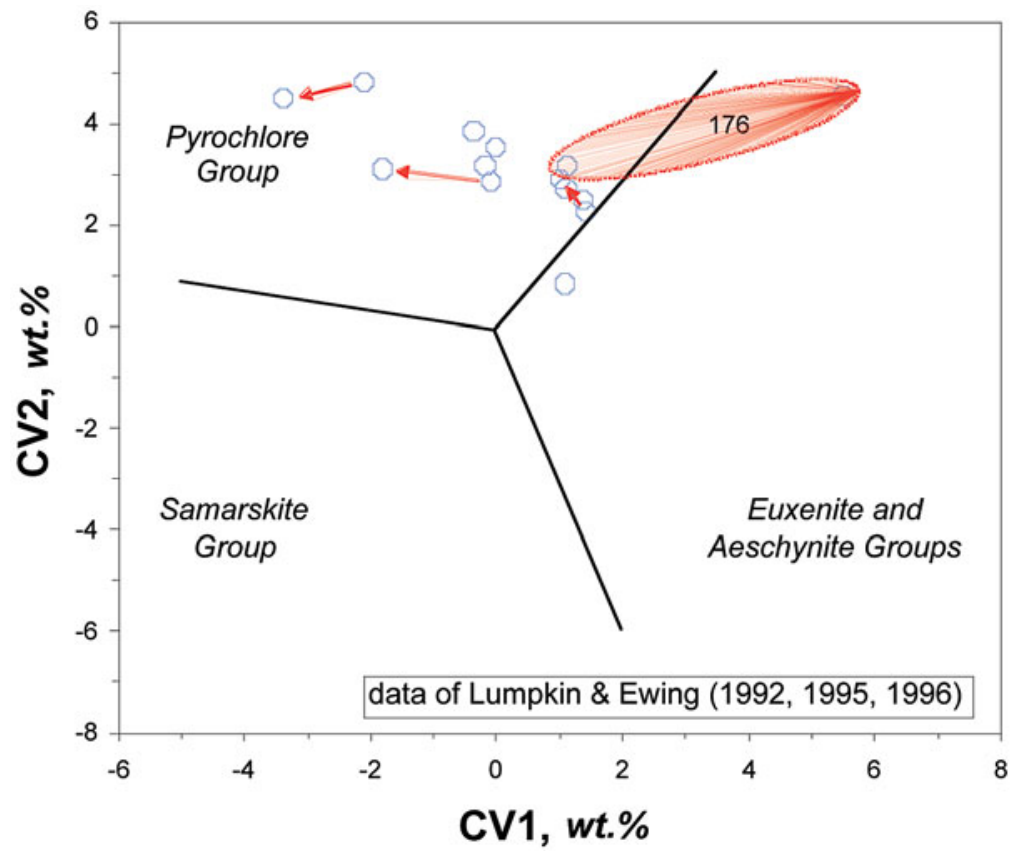

FIG. 5. Plot of the scores for samples of pyrochlore-group minerals from REE-enriched pegmatite, after Lumpkin \& Ewing $(1992,1995,1996)$. Arrows denote alteration paths. 
process of a transformation to liandratite $\mathrm{UNb}_{2} \mathrm{O}_{8}$ and hypothetical $\mathrm{U}_{1.33} \mathrm{Ti}_{2} \mathrm{O}_{8}$. Hints of this behavior lie in its composition: although the anomalous composition is very poor in $A$ cations, its location in Figure 5 cannot be accounted for by $A$-cation loss. Secondly, although it has undergone major amounts of secondary alteration, it is unusually poor in $\mathrm{H}_{2} \mathrm{O}$, contrary to normal behavior. Lumpkin \& Ewing (1992) indicated that these responses to alteration are common in betafite-subgroup minerals; consequently, all compositions of such minerals should be carefully scrutinized when assessing alteration by means of Figure 3.

Figure 6 illustrates the results for samples of samarskite-group minerals from the collections of the Canadian Museum of Nature (all from REE-enriched pegmatite). As the vast majority of the samples had not previously been compositionally analyzed nor examined by X-ray diffraction, the dataset is rife with misidentifications. Figure 6 indicates that the misidentified samples are actually members of the euxenite or aeschynite groups; detailed inspection of these compositions shows that all are euxenite-(Y). As fresh and altered regions of both correctly and incorrectly identified samples were measured, the vectors of Figure 6 describe alteration of both samarskite- and euxenite-group minerals. The orientation of the vectors shows that hydration and addition of $\mathrm{Si}$ and $\mathrm{Al}$ were the predominant processes during the alteration of samarskite-group minerals, as well as euxenite-group minerals, in accordance with the findings of Ewing (1976).

In summary, euxenite-, aeschynite- and samarskitegroup minerals all behave similarly during alteration, the predominant effect being hydration and addition of $\mathrm{Si}$ and $\mathrm{Al}$. Other minor effects include (Y + REE) exchange, but these are less common and generally less significant than the predominant effect. The alteration of pyrochlore-group minerals is more complex, as it also involves loss of total $A$-cations, or loss or gain of specific types of $A$-site cations. This is easily understood. The $B_{2} \mathrm{O}_{6}$ framework of the pyrochlore structure is relatively inert, hence $B$ cations are generally unaffected by alteration (Ercit et al. 1993, Lumpkin \& Ewing 1992, 1995, 1996). The A-site cations of the pyrochlore structure are generally more highly coordinated than the $A$-site cations of the euxenite, aeschynite and samarskite structures, and are generally lower in charge $\left(e . g ., \mathrm{Na}^{+}, \mathrm{Ca}^{2+}\right)$ than the main $A$-site cations of the euxenite, aeschynite and samarskite structures (e.g., $\mathrm{Y}^{3+}, \mathrm{REE}^{3+}, \mathrm{Fe}^{2+}, \mathrm{Fe}^{3+}, \mathrm{Ca}^{2+}$ ). As a consequence, the strength of an average $A-\mathrm{O}$ bond in the pyrochlore structure is considerably weaker than that of either the euxenite, aeschynite or samarskite structures; processes involving $A$-cation exchange or total $A$-cation loss thus should be more significant in pyrochlore-group minerals. As the fergusonite structure has $\mathrm{Y}^{3+}$ and $\mathrm{REE}^{3+}$ as the main $A$-site cations, fergusonite-group

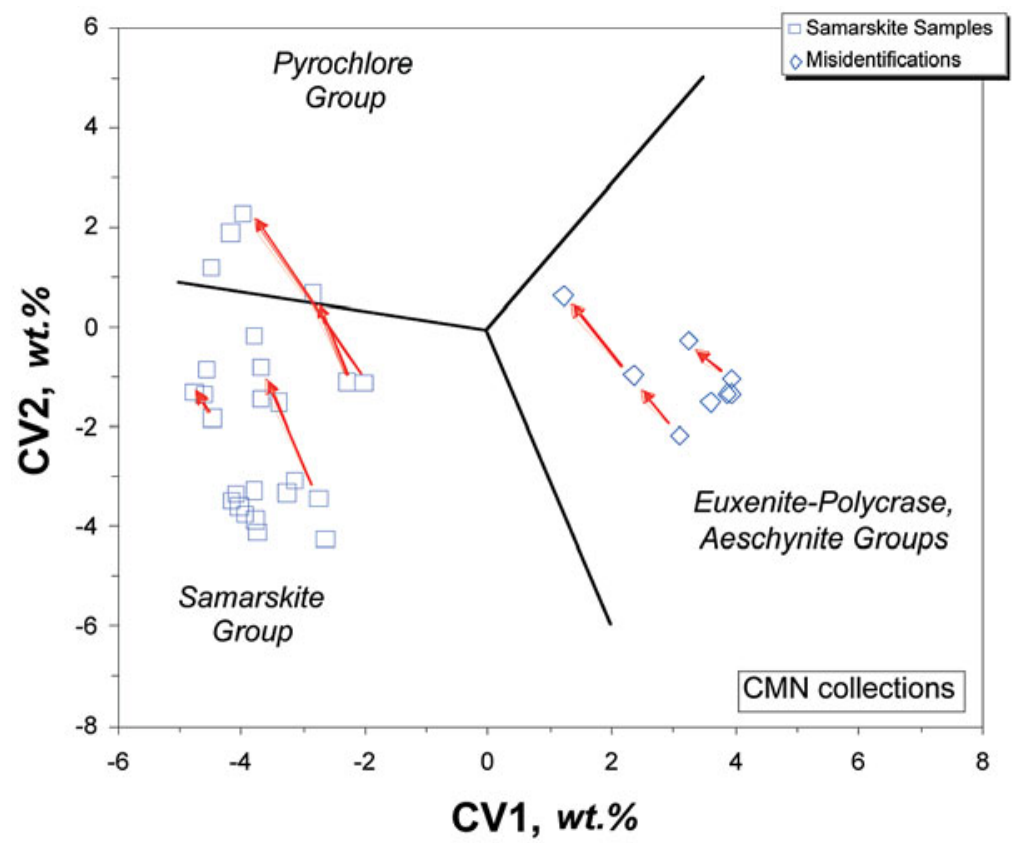

FIG. 6. Plot of the scores for samples of apparent members of the samarskite group, Canadian Museum of Nature (CMN) collections. All samples are from bodies of REEenriched granitic pegmatite. Arrows denote alteration paths. 
minerals are expected to behave similarly to euxenite-, aeschynite- and samarskite-group minerals with regards to alteration effects; i.e., compositions of fergusonitegroup minerals in plots like Figure 3 should become shifted upward and to the left with alteration.

In conclusion, the bulk alteration of samarskite-, aeschynite-, euxenite-, and fergusonite-group minerals should displace the data points in canonical variable plots based on Figures 2 and 3 upward and toward the left of the diagram. This shift has the following effect: data points for altered samples of fergusonitegroup minerals will be displaced toward the upper left boundary between the samarskite and fergusonite groups, and data points for altered samples of samarskite-, euxenite- and aeschynite-group minerals will be displaced toward their respective boundaries with the pyrochlore group. Many data points for samples of pyrochlore-group minerals will be displaced within the field for the pyrochlore group; however, because of the complex alteration history of pyrochlore-group minerals (Lumpkin \& Ewing 1992, 1995, 1996), some exceptions to this behavior should be expected.

\section{Classification of published data}

As a test of the suitability of a statistical basis of mineral classification, three-group canonical scores were calculated for compositions of (Y,REE,U,Th)$(\mathrm{Nb}, \mathrm{Ta}, \mathrm{Ti})$ oxide minerals from well-known compilations (Palache et al. 1944, Vlasov 1966). The dataset includes well-characterized to poorly characterized samples, and exotic compositional varieties. A large proportion of the older datasets in these compilations report only $\Sigma \mathrm{Y}_{2} \mathrm{O}_{3}$ (sum total of oxides of $\mathrm{Y}+\mathrm{HREE}$ ), which precludes use of the three-group model, above, in the calculations. Consequently, the three-group model was recalculated for older analyses by combining the independent variables $\mathbf{Y}$ and HREE as a new variable, $\mathbf{Y}^{*}$. The result was:

$$
\begin{aligned}
& \text { CV1 }=0.233 \mathbf{~ N a}+0.104 \mathbf{C a}-0.115 \mathbf{F e}^{*} \\
& +0.405 \mathbf{P b}+0.174 \mathbf{Y}^{*}+0.261 \mathbf{L R E E} \\
& +0.096 \mathbf{U}^{*}+0.301 \mathbf{T i}+0.095 \mathbf{~ N b}+0.107 \mathbf{T a}^{*} \\
& -12.22 \text { (oxide wt. } \% \text { ) } \\
& \text { CV2 }=0.119 \mathbf{~ N a}-0.126 \mathbf{C a}-0.334 \mathbf{F e} \mathbf{F}^{*} \\
& -0.172 \mathbf{P b}-0.361 \mathbf{Y}^{*}-0.287 \mathbf{L R E E}-0.197 \mathbf{U}^{*} \\
& -0.105 \mathbf{T i}-0.182 \mathbf{~ N b}-0.116 \mathbf{T a}^{*} \\
& +18.54 \text { (oxide wt. } \%)
\end{aligned}
$$

When the oldest analyses were done (pre-1900), no distinction was possible amongst $(\mathrm{Y}+\mathrm{REE})$; consequently, only the sum of their oxides is reported in these compilations. Because of the very different eigenvectors for LREE versus Y and HREE, it is not wise to merge all three variables and perform another recalculation. Consequently, for each pertinent composition, propor- tions of $\mathbf{Y}^{*}$ and LREE were estimated from the total (Y $+\mathrm{REE}$ ) tally on the basis of crystal-chemical trends for the groups: LREE = two-thirds of the total $(Y+R E E)$ for aeschynite-group minerals, one-half for pyrochloregroup minerals, and one-quarter for all samples of other groups, with $\mathbf{Y}^{*}$ making up the remainder of the $(\mathrm{Y}+$ REE) for all cases.

The results of the calculations are shown in Figures 7 and 8, based on Palache et al. (1944) and Vlasov (1966), respectively. In general, the classification is excellent, with the vast majority of samples falling into their predicted groups, even members of the fergusonite group. However, it should be noted that some of these compositions were used in the statistical modeling, hence some degree of the goodness of fit is predetermined. Note that two sets of boundaries are shown in Figures 7 and 8; the solid lines represent the preferred model with Y and HREE as separate variables, the dashed lines represent the model with $\mathbf{Y}^{*}$. In general, the compilation of Vlasov (1966) clusters much better about the group means than that of Palache et al. (1944). This is in part attributable to the improvement in analytical methods between the timing of the two monographs, and to the omission by Vlasov (1966) of many highly altered samples in his compilation.

Some features of altered samples are consistent within both diagrams. As predicted, altered fergusonite-(Y) sample 4 of Palache et al. (1944) plots in the vicinity of the left boundary between the samarskite and fergusonite groups (solid black triangle in Fig. 7). Altered euxenite-(Y) sample 11 of Palache et al. (1944) plots in the vicinity of the boundary between the euxenite-aeschynite and the pyrochlore groupings (solid black diamond in Fig. 7). Betafite from Tangen, Norway plots in the vicinity of the boundary between the pyrochlore and aeschynite-euxenite groupings (dotted ovals in Figs. 7, 8). It is highly titanian and highly hydrated like many severely altered samples of betafite that have undergone major-element redistribution (Lumpkin \& Ewing 1992), and is interpreted as such. Furthermore, Hogarth (1977) reported a personal communication from W.L. Griffin indicating that betafite ("titanopyrochlore") from the Tangen quarry is composed of upward of five different phases. A large number of altered samarskite-group minerals in the Palache et al. (1944) compilation plot in the vicinity of the boundary between the samarskite and pyrochlore groups. Two such compositional varieties of samarskite are "ampangabeite" and "hjelmite", which are shown in Figure 7 to be altered varieties of samarskite-group minerals. Note, however that (1) the "ampangabeite", sample 5 of Palache et al. (1944), would actually seem to be a member of the pyrochlore group (circled square in Fig. 7); (2) "hjelmite" was redefined by Crook (1979) as "yttromicrolite", which itself was later discredited. The present interpretation of "hjelmite" as an altered samarskite-group mineral is more consistent with its 


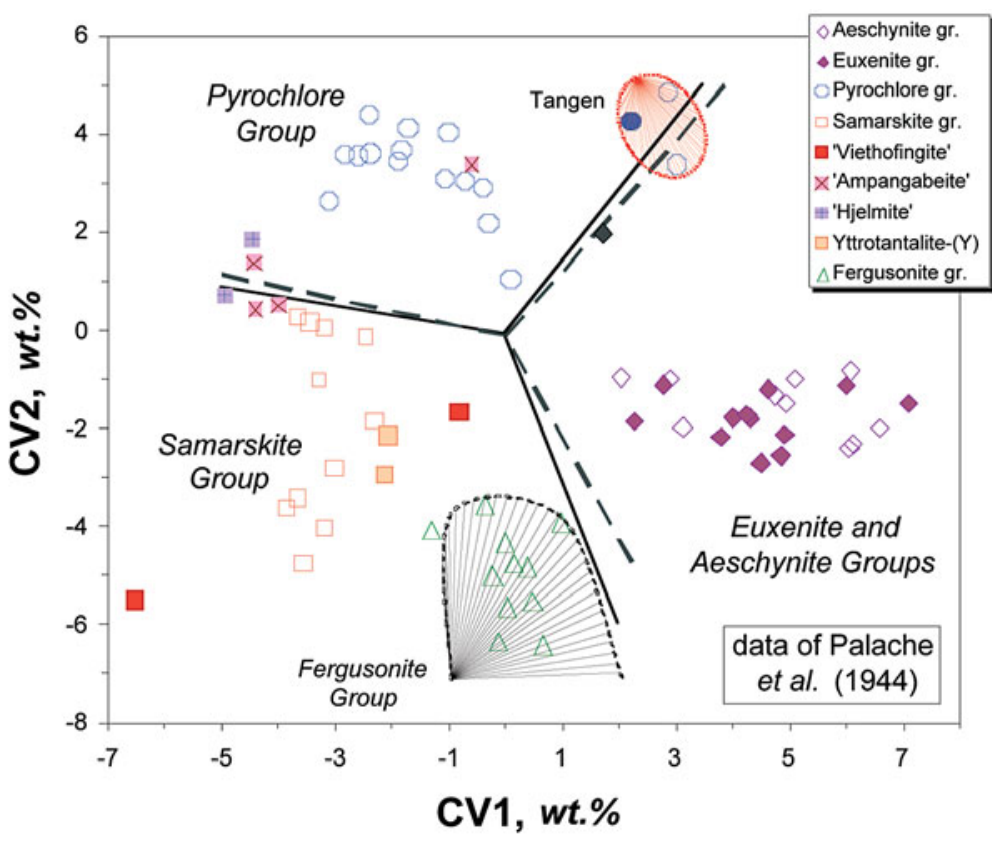

FIG. 7. Classification of samples published in Dana's System of Mineralogy (Palache et al. 1944). Boundaries in coarse, dashed rule are for a model with $\mathbf{Y}^{*}=\mathbf{Y}+$ HREE; solid boundaries are as in Figure 2.

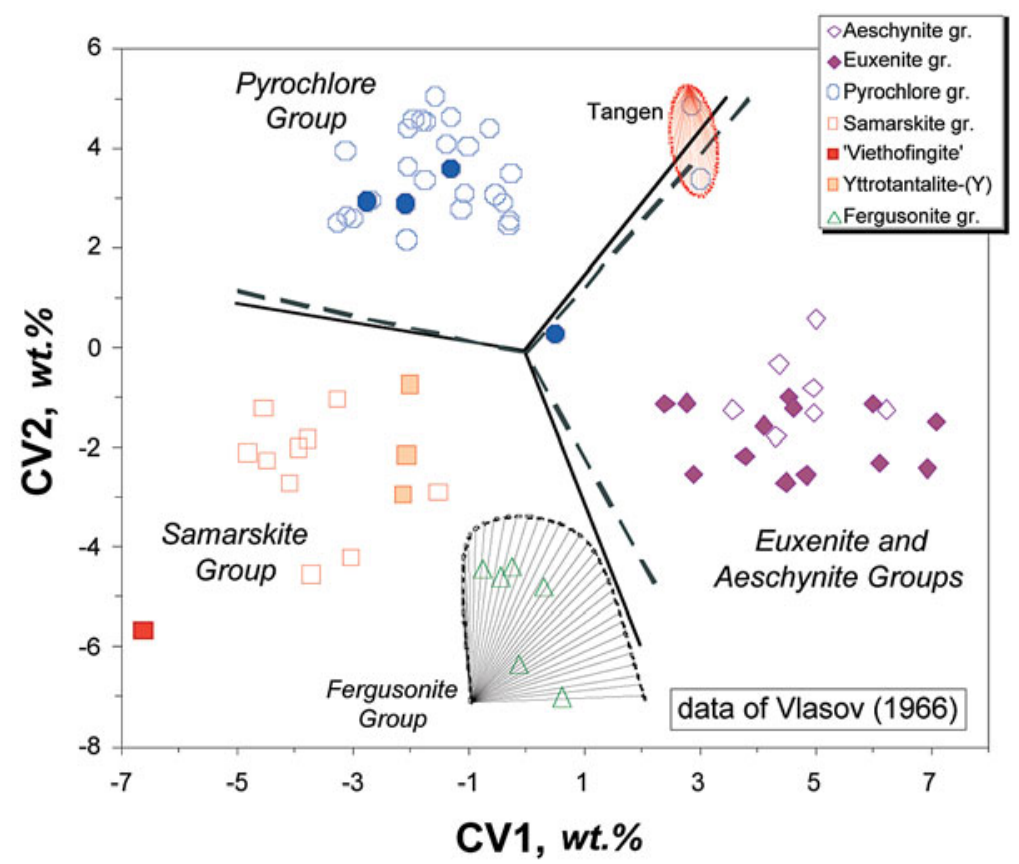

FIG. 8. Classification of samples published in Vlasov (1966). Boundaries are as in Figure 7. 
anisotropic optical characteristics (Palache et al. 1944). "Viethofingite" is confirmed to be a variety of samarskite-group mineral, perhaps one with some degree of contamination, as the data point for "viethofingite" plots outside the normal range for samarskite-group minerals, but not in a manner easily accounted for by conventional modes of alteration. Yttrotantalite-(Y) is considered by most (e.g., Vlasov 1966, Vorma \& Hoffrén 1965) as a member of the samarskite group; however, Palache et al. (1944) assigned it to the fergusonite group. In Figures 7 and 8, yttrotantalite-(Y) plots well within the field for the samarskite group, thus is conclusively shown for the first time to be the tantalumdominant analogue of samarskite-(Y).

\section{CONCLUSIONS}

1. Canonical discriminant analysis is a reliable approach in the identification of (Y,REE,U,Th)$(\mathrm{Nb}, \mathrm{Ta}, \mathrm{Ti})$ oxide minerals. Differentiation among the pyrochlore, samarskite, fergusonite and aeschyniteeuxenite groupings can be achieved by means of plots derived from two canonical variables:

$$
\begin{aligned}
& \text { CV1 }=0.245 \mathbf{~ N a}+0.106 \mathbf{C a}-0.077 \mathbf{F e}^{*} \\
& +0.425 \mathbf{P b}+0.220 \mathbf{Y}+0.280 \mathbf{L R E E} \\
& +0.137 \mathbf{H R E E}+0.100 \mathbf{U}^{*}+0.304 \mathbf{T i}+0.097 \mathbf{~ N b} \\
& +0.109 \mathbf{T a}^{*}-12.81 \text { (oxide wt. } \% \text { ) } \\
& \text { CV2 }=0.102 \mathbf{~ N a}-0.113 \mathbf{C a}-0.371 \mathbf{F e} * \\
& -0.167 \mathbf{P b}-0.395 \mathbf{Y}-0.280 \mathbf{L R E E} \\
& -0.265 \mathbf{H R E E}-0.182 \mathbf{U}^{*}-0.085 \mathbf{T i}-0.166 \mathbf{~ N b} \\
& -0.146 \mathbf{T a}^{*}+17.29 \text { (oxide wt. } \% \text { ) }
\end{aligned}
$$

where $\mathbf{F e}^{*}=\mathrm{FeO}+\mathrm{Fe}_{2} \mathrm{O}_{3}+\mathrm{MnO}, \mathbf{U}^{*}=\mathrm{UO}_{2}+\mathrm{UO}_{3}+$ $\mathrm{U}_{3} \mathrm{O}_{8}+\mathrm{ThO}_{2}$, and $\mathrm{Ta}^{*}=\mathrm{Ta}_{2} \mathrm{O}_{5}+\mathrm{WO}_{3}$.

2. A working differentiation of the euxenite group from the aeschynite group can be done according to the preliminary calculations of Ewing (1974): the aeschynite group has LREE $>0.326 \mathbf{T i}-0.060 \mathbf{~ N b}+$ 3.1 (oxide wt.\%), whereas for the euxenite group, the converse applies.

3. Distinctions amongst members of individual groups should follow published guidelines or, in their absence, the "50\% rule" of Nickel (1992).

4. Plots of the canonical scores can also be used to monitor the effects of alteration upon the compositions of (Y,REE,U,Th)-(Nb,Ta,Ti) oxide minerals. Compositions that plot near the boundaries between groups typically represent altered samples. Alteration vectors can be used to infer the pre-alteration identity of most seriously affected samples, and are key to the correct interpretation of the pattern of alteration of betafitesubgroup minerals.

5. Yttrotantalite-(Y) is the Ta-dominant analogue of samarskite-(Y); "hjelmite", "viethofingite" and "ampangabeite" are altered varieties of samarskitegroup minerals.

\section{ACKNOWLEDGEMENTS}

I thank referee J.-F. Lenain and Robert F. Martin for constructive reviews of the manuscript. Thanks (?) are owed to unknown substance-abusers of Vancouver, who removed an earlier, cruder version of the study, along with my laptop computer, from the car of Dr. Lee Groat (UBC) in 1999. Financial support for the project was provided by a Canadian Museum of Nature RAC grant.

\section{REFERENCES}

BuRT, D.M. (1989): Compositional and phase relations among rare earth element minerals. In Geochemistry and Mineralogy of Rare Earth Elements (B.R. Lipin \& G.A. McKay, eds.). Rev. Mineral. 21, 259-307.

Crook, W.W., III (1979): Yttromicrolite, a new mineral, and a redefinition of hjelmite. Am. Mineral. 64, 890-892.

ERCIT, T.S. (2006): REE-enriched granitic pegmatites. In Rare Element Geochemistry and Ore Deposits (R. Linnen \& I. Samson, eds.). Geol. Assoc. Can., Short Course Notes 17, (in press).

ČERnÝ, P. \& HaWthorne, F.C. (1993): Cesstibtantite - a geologic introduction to the inverse pyrochlores. Mineral. Petrol. 48, 235-255.

EwING, R.C. (1974): Mineralogy of Metamict Rare Earth $\mathrm{AB}_{2} \mathrm{O}_{6}$-Type Niobium - Tantalum - Titanium Oxides. Ph.D. thesis, Stanford Univ., Stanford, California.

(1975): Alteration of metamict, rare-earth, $\mathrm{AB}_{2} \mathrm{O}_{6-}$ type $\mathrm{Nb}-\mathrm{Ta}-\mathrm{Ti}$ oxides. Geochim. Cosmochim. Acta 39, 521-530.

(1976): A numerical approach toward the classification of complex, orthorhombic, rare-earth, $\mathrm{AB}_{2} \mathrm{O}_{6}$-type Nb-Ta-Ti oxides. Can. Mineral. 14, 111-119.

Gong WeILANG (1990): On high-temperature phase transitions of metamict fergusonite group minerals from Baiyun Obo. Int. Mineral. Assoc., 15th Gen. Meeting,, Abstr. Vol. 2, 934-936.

Hanson, S.L., Simmons, W.B., Falster, A.U., Foord, E.E. \& Lichte, F.E. (1999): Proposed nomenclature for samarskite-group minerals: new data on ishikawaite and calciosamarskite. Mineral. Mag. 63, 27-36.

HoGARTH, D.D. (1977): Classification and nomenclature of the pyrochlore group. Am. Mineral. 62, 403-410.

Lumpkin, G.R., Chakoumakos, B.C. \& Ewing, R.C. (1986): Mineralogy and radiation effects of microlite from the Harding pegmatite, Taos County, New Mexico. Am. Mineral. 71, 569-588.

\& EwING, R.C. (1992): Geochemical alteration of pyrochlore group minerals: microlite subgroup. Am. Min eral. 77, 179-188. 
$\&$

(1995): Geochemical alteration of pyrochlore group minerals: pyrochlore subgroup. Am. Mineral. 80, 732-743.

$\&$ (1996): Geochemical alteration of pyrochlore group minerals: betafite subgroup. Am. Mineral. 81, 1237-1248.

Mitchell, R.S. (1967): Virginia metamict minerals: X-ray study of fergusonite. Southeast. Geol. 8, 145-153.

NiCKEL, E.H. (1992): Solid solutions in mineral nomenclature. Can. Mineral. 30, 231-234.

Palache, C., Berman, H. \& Frondel, C. (1944): Dana's System of Mineralogy. 1. Elements, Sulfides, Sulfosalts, Oxides (7th ed.). John Wiley \& Sons, New York, N.Y.

Sugitani, Y., SuzuKi, Y. \& Nagashima, K. (1985): Polymorphism of samarskite and its relationship to other structurally related $\mathrm{Nb}-\mathrm{Ta}$ oxides with the $\alpha-\mathrm{PbO}_{2}$ structure. $\mathrm{Am}$. Mineral. 70, 856-866.

SYSTAT Software Inc. (2002): Systat 10.2 statistical software (http://www.systat.com).
Tsunekawa, S., Kamiyama, T., Asano, H. \& Fukuda, T. (1995): Relationship between covalence and displacive phase transition temperature in $R A \mathrm{O}_{4}$ and $\mathrm{Li}_{A} \mathrm{O}_{3}(R=$ rare-earth element and $A=\mathrm{Nb}$ and Ta). J. Solid State Chem. 116, 28-32.

TukeY, J.W. (1958): Bias and confidence in not quite large samples. Ann. Math. Stat. 29, 614.

Vlasov, K.A., ed. (1966): Geochemistry and Mineralogy of Rare Elements and Genetic Types of Their Deposits. II. Mineralogy of Rare Elements. Israel Program for Scientific Translations, Jerusalem, Israel.

Vorma, A. \& HoffréN, V. (1965): On adelpholite and its relation to the minerals of the yttrotantalite - samarskite series. C.R. Soc. géol. Finlande 37, 201-214.

WARNER, J.K. \& EWING, R.C. (1993): Crystal chemistry of samarskite. Am. Mineral. 78, 419-424.

Received November 17, 2003, revised manuscript accepted May 1, 2005. 